\title{
ПРОФЕСІЙНА САМООЦІНКА І СТРАТЕГІЯ ПОВЕДІНКИ МАЙБУТНІХ МЕДИЧНИХ ПРАЦІВНИКІВ У ПРОФЕСІЙНИХ КОНФЛІКТНИХ СИТУАЦІЯХ
}

\author{
Катерина Ушакова \\ кандидат психологічних наук, \\ викладач основ загальної і медичної психології \\ Чернівецький медичний фаховий коледж \\ 58001, Україна, м. Чернівці, вул. Героїв Майдану, 60 \\ U_k_85@ukr.net, http://orcid.org/0000-0002-3653-5432
}

\begin{abstract}
Анотація
Статтю присвячено вивченню професійної самооцінки і стратегій поведінки майбутніх медичних працівників середньої ланки в професійних конфліктних ситуаціях, що $\epsilon$ важливою умовою їхнього подальшого успішного розвитку як фахівців медичної сфери. Мета емпіричного дослідження полягала у виявленні рівнів професійної самооцінки і визначенні стратегій поведінки в професійних конфліктних ситуаціях студентів 1-4-х курсів медичних коледжів упродовж їхнього фахового навчання.

Методи дослідження: теоретичні (аналіз наукової літератури); емпіричні (модифікована методика «Дослідження самооцінки особистості», методика дослідження професійних конфліктних ситуацій у системі «медичний працівник-хворий»); математичної статистики (коефіцієнти кореляції Спірмена і Пірсона, критерій $\varphi^{*}$-кутового перетворення Фішера).

Результати. Емпірично вивчено рівні професійної самооцінки і стратегії поведінки в професійних конфліктних ситуаціях у системі «медичний працівник-хворий» студентів $1-4-\mathrm{x}$ курсів медичних коледжів. 3'ясовано, що до закінчення фахового навчання у медичному коледжі статистично незначуще збільшується кількість студентів із високою, зменшується iз середньою i низькою професійною самооцінкою. Виявлено відмінності стратегій поведінки в професійних конфліктних ситуаціях у системі «медичний працівник-хворий» студентів 1-4-х курсів медичних коледжів. Встановлено статистично значуще зменшення кількості студентів, яким властива агресивність у вирішенні професійних конфліктних ситуацій, і збільшення кількості студентів, яким притаманний самозахист чи слабкість, а також прагнення уникати осуду. Визначено зв'язок професійної самооцінки зі стратегією поведінки в професійних конфліктних ситуаціях студентів медичних коледжів.

Висновки. Впродовж фахового навчання студентів у медичному коледжі дещо змінюються рівні професійної самооцінки і стратегії поведінки в професійних конфліктних ситуаціях у системі «медичний працівник-хворий».
\end{abstract}

Ключові слова: професійна самооцінка, професійні конфліктні ситуації, майбутні медичні працівники, студенти медичних коледжів.

\section{Вступ}

На сучасному етапі трансформування освітньої сфери України актуалізується проблема підвищення ефективності підготовки студентів закладів вищої освіти всіх рівнів як фахівців із високорозвиненою професійною самосвідомістю, що вирізняється позитивним змістом усіх компонентів. В українському суспільстві особливої значущості набуває потреба у таких випускниках закладів вищої освіти, які глибоко засвоїли теоретичні знання, 
оволоділи фаховими компетентностями, а також мають розвинуті професійні уявлення про себе, адекватно оцінюють себе як майбутнього фахівця і регулюють власну поведінку в професійних ситуаціях. Зазначені завдання визначено найважливішими в Законах України «Про освіту» i «Про вищу освіту». В умовах пандемії особливого значення надається процесу фахової підготовки майбутніх медичних працівників у закладах вищої освіти. Тому у вітчизняній психологічній науці й практиці неабиякої актуальності набуває проблема розвитку професійної самосвідомості студентів медичних коледжів.

Проблематиці професійної самосвідомості студентів медичних коледжів присвячено небагато останніх наукових досліджень психологів. В зарубіжній психології вивчалися гендерні особливості самооцінювання професійних мотивів студентами перших курсів медичних коледжів Пакістану. Емпірично встановлено, що респонденти чоловічої статі вище оцінюють власні професійні мотиви, сильніше прагнуть до успіхів у професійній діяльності, порівняно з досліджуваними жіночої статі (Basit Ali Akhlaq \& Kehkashan Arouj, 2014).

У вітчизняній психології досліджувалися окремі аспекти розвитку професійної самосвідомості та «Я-концепції» студентів медичних коледжів. Так, емпірично визначено основні психологічні чинники розвитку професійної «Я-концепції» майбутніх медичних працівників середньої ланки - рівень розвиненості професійної свідомості студентів; їхнє ставлення до майбутньої професійної діяльності; місце фахової спрямованості та прагнення професійної самореалізації в мотиваційній сфері особистості; важливість вибраної професії; рівень актуальності та значущості для них своєї професійної ідентичності (Ушакова, 2018). Виявлено змінювання змісту реальних й ідеальних професійних уявлень про себе в студентів медичних коледжів упродовж фахового навчання (Ushakova, Spivak \& Hladkevych, 2019).

Потреба вивчення професійної самооцінки і стратегій поведінки майбутніх медичних працівників середньої ланки в професійних конфліктних ситуаціях зумовлена відсутністю таких досліджень у сучасній зарубіжній і вітчизняній психологічній науці.

Мета дослідження: емпірично вивчити рівні професійної самооцінки і стратегії поведінки в професійних конфліктних ситуаціях студентів 1-4-х курсів медичних коледжів. Завдання дослідження: 1) визначити рівні професійної самооцінки майбутніх медичних працівників середньої ланки; 2) виявити стратегії поведінки студентів 1-4-х курсів медичних коледжів у професійних конфліктних ситуаціях; 3) вивчити зв'язок професійної самооцінки зі стратегіями поведінки в професійних конфліктних ситуаціях студентів.

\section{Методи дослідження}

Учасниками емпіричного дослідження, яке проводилося в 2019-2020 роках, стали 153 студенти 1-4 курсів медичних коледжів м. Чернівці.

Рівні професійної самооцінки майбутніх медичних працівників середньої ланки (високий, середній і низький) вивчалися за допомогою модифікованої автором методики «Дослідження самооцінки особистості» (Ушакова, 2018). В модифікованій методиці застосовувався перелік професійно-значущих якостей медичного працівника середньої ланки. Досліджувані, після ознайомлення із запропонованим списком, записували такі 20 якостей, які вони визначили найбільш важливими для фахівця медичної сфери. Після цього записані якості ранжувалися ними, а різні ранги (від 1-го до 20-ти; 1-й ранг - найвищий, 20-й - найнижчий) присвоювалися вибраним якостям у контексті «Я-реального» та «Яідеального» (еталон медичного працівника середньої ланки). 
Високий, середній і низький рівні професійної самооцінки студентів визначалися за допомогою коефіцієнта рангової кореляції Спірмена. Статистична значущість відмінностей між рівнями професійної самооцінки майбутніх медичних працівників, студентів 1-4-х курсів встановлювалася за допомогою критерію $\varphi^{*}$-кутове перетворення Фішера. Зв'язок рівнів професійної самооцінки зі стратегіями поведінки студентів у професійних конфліктних ситуаціях вивчався за допомогою коефіцієнта кореляції Пірсона.

Стратегії поведінки майбутніх медичних працівників середньої ланки в професійних конфліктних ситуаціях досліджувалися за допомогою методики «Конфліктні стосунки медсестра-хворий» (Тихонова, 2013). Студентам було запропоновано уважно подивитися і проаналізувати 24 схематичні малюнки з невирішеними остаточно конфліктними ситуаціями професійної взаємодії медичного працівника середньої ланки з хворими. В фрустраційних ситуаціях (наявність перешкод і звинувачень) вони мали зайняти професійну позицію медичного працівника, швидко іï вирішити і дати відповідь хворому. А також записати в бланк прийняте ними рішення в кожній ситуації. Ситуації певною мірою пов'язані між собою і стосуються перешкод або звинувачень.

Унаслідок аналізу відповідей досліджуваних про власне рішення в професійних конфліктних ситуаціях було встановлено їхню переважаючу стратегію - екстрапунітивну, інтрапунітивну або імпунітивну. Основні прояви екстрапунітивної стратегії поведінки студентів - докори й осуд іншого як джерела конфліктної ситуації (агресія). Прояви інтрапунітивної спрямованості - докори, звинувачення й осуд себе як джерела конфліктної ситуації (самозахист, слабкість). Прояви імпунітивної спрямованості - уникнення осуду, незалежно від жодних обставин (толерантність, емоційна стійкість).

\section{Результати та дискусії}

Рівень професійної самооцінки визначає збіг реальних та ідеальних уявлень студентів медичних коледжів про себе як майбутніх медичних працівників середньої ланки.

Одержані результати щодо визначення рівнів професійної самооцінки студентів медичних коледжів подано в табл. 1.

Таблиия 1

Професійна самооцінка майбутніх медичних працівників (\%), n=153

\begin{tabular}{|c|c|c|c|c|}
\hline Рівень / Курс & 1 курс, $\mathrm{n}=37$ & 2 курс, $\mathrm{n}=43$ & 3 курс, $\mathrm{n}=38$ & 4 курс, $\mathrm{n}=35$ \\
\hline Високий & 13,5 & 15,1 & 18,4 & 26,8 \\
\hline Середній & 59,5 & 53,5 & 51,3 & 47,9 \\
\hline Низький & 27 & 31,4 & 30,3 & 25,3 \\
\hline
\end{tabular}

3 табл. 1 видно, що в студентів усіх курсів найбільші кількісні показники стосуються середнього рівня професійної самооцінки, дещо менші - низького і найменші - високого. Нижче детальніше схарактеризовано становлення професійної самооцінки студентів загалом від 1-го до 4-го курсу і зокрема від кожного попереднього до наступного року навчання в медичному коледжі.

Про високий рівень професійної самооцінки свідчить схожість більшості реальних та ідеальних уявлень досліджуваних про себе як майбутніх медичних працівників середньої ланки. Загалом визначені зміни в становленні професійної самооцінки студентів від 1-го до 4-го року навчання на цьому рівні статистично незначущі. Встановлено, що від 1-го до 2-го курсу кількість досліджуваних із високим рівнем самооцінки збільшилася на 1,6\% 
$\left(\varphi^{*}=1,319\right)$. Такі незначні зміни можна пояснити тим, що на 1-му курсі переважає теоретичне навчання і студенти вивчають небагато професійно спрямованих дисциплін. Від 2-го до 3-го курсу навчання студентів кількісні дані високої професійної самооцінки збільшуються також несуттєво - на 3,3\% ( $\left.\varphi^{*}=0,539\right)$. Не зважаючи на те, що впродовж 2-го курсу навчання студенти вивчають вже більше професійно спрямованих дисциплін, як теоретичних, так i практичних, зміни виявилися статистично незначущими. Від 3-го до 4-го курсу навчання кількість студентів із високим рівнем професійної самооцінки збільшилася на 8,4\% $\left(\varphi^{*}=0,751\right)$. Проте встановлені зміни також не є статистично значущими, не зважаючи на збільшення кількості теоретичних і практичних професійно спрямованих дисциплін, а відтак, обсягу фахових знань і появи нових фахових компетентностей.

Свідченням середнього рівня професійної самооцінки виступав частковий збіг реальних та ідеальних уявлень студентів про себе як майбутніх фахівців медичної сфери. Загалом емпірично визначені зміни у становленні професійної самооцінки студентів від 1-го до 4-го року навчання на цьому рівні також виявилися статистично незначущими. Зокрема встановлено, що від 1-го до 2-го курсу кількість студентів із середнім рівнем професійної самооцінки статистично незначуще зменшилася на $6 \%\left(\varphi^{*}=0,54\right)$. Від 2-го до 3-го року курсу кількість студентів із середнім рівнем професійної самооцінки також статистично незначуще зменшилася - на 2,2\% ( $\left.\varphi^{*}=0,314\right)$. Кількість студентів із цим рівнем професійної самооцінки від 3-го до 4-го року також зменшилася статистично несуттєво - на 3,4\% ( $\left.\varphi^{*}=0,12\right)$. Загалом у студентів від 1-го до 4-го року навчання на середньому рівні помічено незначне зменшення кількісних даних професійної самооцінки.

Низький рівень професійної самооцінки студентів засвідчував збіг незначної кількості їхніх реальних та ідеальних уявлень про себе як майбутніх медичних працівників. Загалом емпірично визначені зміни в становленні професійної самооцінки студентів від 1-го до 4-го року навчання на цьому рівні статистично незначущі. Так, від 1-го до 2-го курсу кількість студентів із низьким рівнем професійної самооцінки статистично незначуще збільшилася на $4,4 \% \quad\left(\varphi^{*}=0,544\right)$. Кількість студентів із цим рівнем від 2-го до 3-го курсу також статистично незначуще зменшилася - на $1,1 \%\left(\varphi^{*}=0,094\right)$. Від 3-го до 4-го року навчання кількість студентів із низьким рівнем професійної самооцінки статистично незначуще зменшилася - на 5\% $\left(\varphi^{*}=0,559\right)$.

Отож, найбільша кількість майбутніх медичних працівників мають середній рівень професійної самооцінки, що свідчить про частковий збіг їхніх реальних та ідеальних уявлень про себе як фахівця медичної сфери. Значно менша - низький, що засвідчує значні відмінності реальних та ідеальних уявлень студентів про себе як майбутніх медичних працівників. Найменша - високий, що підтверджує досить великий збіг реальних та ідеальних уявлень досліджуваних про себе як майбутніх фахівців медичної сфери.

Впродовж фахового навчання у медичному коледжі статистично незначуще змінюються кількісні дані рівнів професійної самооцінки студентів. Із одного боку, на підвищення рівня професійної самооцінки студентів повинно впливати збільшення кількості теоретичних і практичних професійно спрямованих дисциплін із кожним наступним роком їхнього фахового навчання. 3 іншого боку, ймовірно студенти не досить високо оцінюють себе, як фахівця, не маючи досвіду професійної діяльності в медичних закладах.

Виокремлено екстрапунітивну, інтрапунітивну й імпунітивну стратегії поведінки медичного працівника в професійних конфліктних ситуаціях. Одержані кількісні дані, які 
стосуються стратегій поведінки студентів медичних коледжів у професійних конфліктних ситуаціях, подано в табл. 2.

Таблиия 2

Стратегії поведінки майбутніх медичних працівників у конфліктних професійних ситуаціях $(\%), \mathbf{n = 1 5 3}$

\begin{tabular}{|c|c|c|c|c|}
\hline \multirow{2}{*}{ Стратегія } & \multicolumn{4}{|c|}{ Kурс } \\
\cline { 2 - 5 } & 1 курс, $\mathrm{n}=37$ & 2 курс, $\mathrm{n}=43$ & 3 курс, $\mathrm{n}=38$ & 4 курс, $\mathrm{n}=35$ \\
\hline Екстрапунітивна & 29,7 & 26,7 & 23,7 & 21,1 \\
\hline Інтрапунітивна & 46 & 47,7 & 50 & 52,1 \\
\hline Імпунітивна & 24,3 & 25,6 & 26,3 & 26,8 \\
\hline
\end{tabular}

3 табл. 2 помітно, що найбільші кількісні дані стосуються інтрапунітивної стратегії поведінки студентів, дещо менші - екстрапунітивної та імпунітивної. Загалом зафіксовано статистично незначуще зменшення кількості досліджуваних із екстрапунітивною спрямованістю поведінки і несуттєве збільшення з інтрапунітивною та імпунітивною.

Емпірично визначено, що кількість студентів із екстрапунітивною стратегією поведінки статистично незначуще зменшується: від 1-го до 2-го курсу на $3 \%\left(\varphi^{*}=0,41\right)$, від 2-го до 3-го курсу також на 3\% ( $\left.\varphi^{*}=0,198\right)$, від 3-го до 4-го курсу на 2,6\% $\left(\varphi^{*}=0,081\right)$. Вочевидь, до 4-го курсу фахового навчання майбутні медичні працівники середньої ланки 3 цією стратегією поведінки усвідомлюють важливість уникнення агресивності в професійних взаємодіях, а також докорів і осуду хворого як ймовірного джерела конфліктної ситуації. Наприклад, студенти 1-го і 2-го курсів найчастіше в ситуації, що стосується відмови хворого від припису лікаря, приймали таке рішення: «Потрібно виконувати приписи лікаря, інакше зашкодите власному здоров’ю» (Ю., 16 р.), «Ви створюєте загрозу для свого здоров'я!» (Г., 17 р.). Студенти 3-го і 4-го курсів приймали таке рішення в цій ситуації: «Надалі неухильно дотримуйтеся призначень лікаря» (С., 18 р.), «Ваше одужання буде тривати довше, якщо не будете виконувати приписів лікаря» (А., 20 р.).

Кількість досліджуваних 3 інтрапунітивною стратегією поведінки статистично незначуще збільшується: від 1-го до 2-го курсу на 1,7\% ( $\left.\varphi^{*}=0,259\right)$, від 2-го до 3-го курсу на $2,3 \%\left(\varphi^{*}=0,108\right)$, від 3-го до 4-го курсу на $2,1 \%\left(\varphi^{*}=0,12\right)$. Студенти медичного коледжу 3 такою стратегією поведінки схильні до самозахисту і виявляють слабкість. Вони засуджують i звинувачують себе в професійних конфліктних ситуаціях, як джерело таких ситуацій. Наприклад, майбутні медичні працівники запропонували таке рішення ситуації про помилку 3 їхнього боку: «Прошу вибачення, обіцяю швидко виправити цю помилку» (Р., 16 р.), «Дуже перепрошую за мою неуважність» (Г., 17 р.), «Перепрошую, більше таких ситуацій не буде повторюватися» (М., 18 р.), «Прошу вибачення, це вийшло випадково» (Г., 20 р.).

Статистично незначуще збільшується кількість досліджуваних із імпунітивною спрямованістю поведінки: від 1-го до 2-го курсу на 1,3\% ( $\left.\varphi^{*}=0,134\right)$, від 2-го до 3-го курсу на $0,7 \%\left(\varphi^{*}=0,072\right)$, від 3-го до 4-го курсу на $0,5 \%\left(\varphi^{*}=0,06\right)$. Студенти медичного коледжу 3 такою стратегією поведінки схильні до уникнення осудів у професійних конфліктних ситуаціях. Водночас вони емоційно стійкі та виявляють толерантність у таких ситуаціях. Майбутні медичні працівники з імпунітивною спрямованістю поведінки запропонували такі вирішення ситуації про обурення пацієнта щодо їхньої відсутності на робочому місці: «Так, мене не було, оскільки дуже багато хворих, яким я терміново надавала допомогу. Чим можу допомогти Вам?» (К., 17 р.), «Моя відсутність пояснюється тим, що виконувала термінову роботу. В чому полягає Ваше звертання? Готова зараз допомогти Вам» (В., 18 р.), «Вибачте, 
що Вам довелося мене чекати. Багато пацієнтів потребували моєї термінової допомоги» (Р., 20 р.). Отже, впродовж фахового навчання статистично несуттєво зменшується кількість студентів медичних коледжів із екстрапунітивною і збільшується 3 інтрапунітивною й імпунітивною стратегією поведінки.

Також встановлено статистично значущий зв'язок рівнів професійної самооцінки зі стратегією поведінки у професійних конфліктних ситуаціях майбутніх медичних працівників середньої ланки. Високий рівень професійної самооцінки студентів пов'язаний із екстрапунітивною стратегією поведінки ( $\mathrm{r}=0,672$ для $\mathrm{p} \leq 0,01)$, середній -3 імпунітивною $(\mathrm{r}=0,567$ для $\mathrm{p} \leq 0,01)$, низький -3 інтрапунітивною ( $\mathrm{r}=0,548$ для $\mathrm{p} \leq 0,01)$. Досліджувані 3 високим рівнем професійної самооцінки схильні виявляти агресію, докоряти і засуджувати іншого, зокрема хворого, як джерела конфлікту. Студентам із середнім рівнем професійної самооцінки властива емоційна стійкість і прагнення уникати будь-якого осуду, не зважаючи на обставини. Досліджувані з низьким рівнем професійної самооцінки виявляють слабкість, схильні засуджувати і звинувачувати себе як джерело конфліктної ситуації.

\section{Висновки}

За результатами проведеного емпіричного дослідження встановлено, що впродовж фахового навчання статистично значущих змін у розвитку професійної самооцінки студентів медичних коледжів не відбувається. На кожному курсі навчання найбільша частина (майже половина) майбутніх медичних працівників оцінюють себе як фахівця середньо, дещо менша (майже третина) - низько, найменша (майже п'ята частина) - високо. Помічено статистично незначуще зменшення кількості досліджуваних із екстрапунітивною і збільшення 3 інтрапунітивною й імпунітивною стратегіями поведінки. Визначено статистично значущий зв'язок професійної самооцінки зі стратегією поведінки студентів медичних коледжів у професійних конфліктних ситуаціях. Високий рівень професійної самооцінки досліджуваних пов'язаний із екстрапунітивною стратегією поведінки, середній - з імпунітивною, низький з інтрапунітивною. Перспективи подальших досліджень полягають у розробці ефективних психологічних технологій для підвищення рівнів професійної самооцінки і саморегуляції поведінки в професійних конфліктних ситуаціях у студентів медичних коледжів.

\section{Література}

1. Ушакова, К.Ю. (2018). Психологічні чинники становлення професійної «Я-концепції» у студентів медичних коледжів. (Дис. канд. психол. наук). Київ.

2. Тихонова, И.В. (2013). Опыт модификации методики изучения фрустрационных реакций С. Розенцвейга для изучения специфики реагирования медсестер в профессиональных конфликтных ситуациях. Медицинская психология в России, Т. 5, 5(22), 1-13. doi: 10.24411/2219-8245-2013-15100

3. Basit Ali, Akhlaq, \& Kehkashan, Arouj. (2014). Study on the Self Esteem and Strength of Motivation of Medical Students.

Retrieved from http://www.ijbhtnet.com/journals/Vol_4_No_5_October_2014/8.pdf

4. Ushakova, K.Yu., Spivak, L.M., \& Hladkevych, M.I. (2019). Peculiarities of Professional "Selfimage" Development of the Future Medical Workers. Problems of modern psychology, 2(16), 125-130. http://doi.org/10.26661/2310-4368-2019-2-16-20

\section{References}

1. Ushakova, K.Yu. (2018). Psykholohichni chynnyky stanovlennia profesiinoi «Ya-kontseptsii»u studentiv medychnykh koledzhiv [Psychological Factors of Becoming a Professional "Iconcept" for students of medical colleges]. Candidate's thesis. Kyiv [in Ukrainian]. 
2. Tikhonova, I.V. (2013). Opyt modifikacii metodiki izuchenija frustracionnyh reakcij S. Rozencvejga dlja izuchenija specifiki reagirovanija medsester v professional'nyh konfliktnyh situacijah [The experience of modifying the instrument of studying S. Rozenzweig's frustration responses for investigating the specifics of nurses' responding in professional conflict situations]. Medicinskaja psihologija v Rossii [Medical psychology in Russia], Vol. 5, 5(22), 113. doi: 10.24411/2219-8245-2013-15100 [in Russian].

3. Basit Ali, Akhlaq, \& Kehkashan, Arouj. (2014). Study on the Self Esteem and Strength of Motivation of Medical Students.

Retrieved from http://www.ijbhtnet.com/journals/Vol_4_No_5_October_2014/8.pdf

4. Ushakova, K.Yu., Spivak, L.M., \& Hladkevych, M.I. (2019). Peculiarities of Professional "Selfimage" Development of the Future Medical Workers. Problems of modern psychology, 2(16), 125-130. http://doi.org/10.26661/2310-4368-2019-2-16-20

\title{
PROFESSIONAL SELF-ESTEEM AND BEHAVIOR STRATEGY OF FUTURE MEDICAL WORKERS IN PROFESSIONAL CONFLICT SITUATIONS Kateryna Ushakova PhD in Psychology, Senior Teacher of the basics of General and Medical Psychology Chernivtsi Medical Vocational College
}

60, Heroiv Maidanu Str., Chernivtsi, Ukraine, 58001

U_k_85@ukr.net, http://orcid.org/0000-0002-3653-5432

\begin{abstract}
The article is devoted to the study of professional self-esteem and behavioral strategies of future mid-level medical workers in professional conflict situations, which is an important condition for their further successful development as medical professionals. The purpose of the empirical study was to identify levels of professional self-esteem and determine strategies for behavior in professional conflict situations of students in grades 1-4 of medical colleges during their professional training. Research methods: theoretical (scientific literature analysis); empirical (modified method "Study of self-esteem", a method of studying professional conflict situations in the system "medical worker-patient"); mathematical statistics (Spearman's and Pearson's correlation coefficient, Fischer's angular transformation criterion $\left.\varphi^{*}\right)$.

Results. The levels of professional self-esteem and the strategies of behavior in professional conflict situations in the system of "medical worker-patient" among the medical college students of 1-4 year of study are empirically studied. It has been found that by the end of professional training in the medical college, the number of students with a high professional self-esteem slightly increases statistically, while the number of students with medium and low professional self-esteem decreases. Differences of behavioral strategies in professional conflict situations in the system of "medical worker-patient" among the medical college students of 1-4 year of study are revealed. There was a statistically significant decrease in the number of students who are aggressive in resolving professional conflict situations, and an increase in the number of students who are characterized by self-defense or weakness, as well as the desire to avoid condemnation. The connection between the professional self-esteem and the strategy of behavior in professional conflict situations of medical college students is traced.

Conclusions. During the professional training of students in the medical college, the levels of professional self-esteem and behavioral strategies in professional conflict situations in the system "medical worker-patient" change somewhat.
\end{abstract}

Keywords: professional self-assessment, professional conflict situations, future medical workers, medical college students. 